\title{
1
}

\section{REVISIÓN CIENTÍFICA}

\section{NOTA DE LA DIRECCION}

El autor ha sido Profesor de Agronomía de Pastos en Lincoln University (CanterburyNueva Zelanda) hasta su jubilación a finales de 1995. Fue Presidente de la New Zealand Grassland Association. Es autor de los capítulos de manejo de pastos y conservación de la hierba (ensilado y henificado) del libro Pastures: their ecology and management, editado por el Profesor Langer (V. referencias bibliográficas).

*The author was a Senior Lecturer in Pasture Agronomy at Lincoln University, Canterbury: New Zealand from 1967 to 1995. He was President of the New Zealand Grassland Association in 1987-88, and has written chapters on pasture management, legume agronomy; and herbage conservation in two books concerned with pastures. 


\title{
THE MANAGEMENT OF PASTURES FOR GRAZING
}

\author{
MICHAEL L. SMETHAM \\ Lincoln University. Canterbury. \\ Nueva Zelanda (New Zealand)
}

\section{SUMMARY}

Past research into pasture management is examined together with possible reasons for the difficulty of putting the results of this research into practice. Guidelines are proposed, based on characteristics of the pasture canopy, for both continuous and rotational grazing. Reasons for the lower productivity of the pasture-grazing animal system at both high and low levels of herbage mass are examined. Variation of the general relationship between herbage mass and productivity by seasonal differences of climate and grass reproduction is discussed. The results are given of recent studies of the effect of interval and severity of grazing on production under rotational grazing. Comparisons are made between herbage production obtained from continuous grazing and rotational grazing, and the difficulties inherant in this comparison are considered. Pasture quality is defined in terms of green leaf and dead material. The influence of management to obtain different levels of utilisation, and to control grass reproductive growth is discussed.

It is concluded that the amount of leaf present in pasture is of prime importance in determining the productivity of the canopy, and the value of this for animal feeding. The presence of dead material can interfere with herbage productivity and also reduce the quality of the sward for animals. Pastures and grazing animals interact strongly, and maximum productivity depends on achieving the optimum balance between these two components.

Key words: Set-stocking, continuous grazing, rotational grazing.

\section{INTRODUCTION}

This paper explores aspects of the management of pastures in moist temperate climates where scientific research has made a contribution to our understanding of the processes involved. It is not however an exhaustive review of this large topic. Rather it is a discourse, the findings of which may be a guide to practice. 


\section{THE SEARCH FOR GUIDELINES}

Professor Martin Jones (1933) from Aberystwyth, Wales was probably one of the first people to examine the effects of length of spell and closeness of grazing on pasture yield and composition. Since then, and up to the early ' 80 's a large amount of research has been conducted both from the general pasture and specific species points of view. seeking the best management to maximise yield. Typical examples are the investigations of Jennifer Clark et al., (1974) who found that grazing closely rather than laxly gave highest yield, and Brougham (1959) who showed that long spells between grazing gave highest yields. Boswell (1977) found that cocksfoot needed a longer spell than ryegrass, unless it was grazed laxly. Some work eg Matches (1966) suggested that short spells were acceptable provided defoliation was not close, but other authors eg Morris (1969), and Campbell (1969) have demonstrated reduced green herbage production due to the dead material build up associated with lax defoliation. However these results and many like them have been found difficult to apply in practice. Parsons and Johnson. (1986) consider this is because guidelines for management based on interval and intensity are not valid without specific qualification as to climate, residual dry matter levels and canopy structure. They suggest that descriptors of "sward state" ie leaf area index, height or herbage mass ( $\mathrm{kg} \mathrm{DM} / \mathrm{ha}$ ) are the only relevant guides to (potential) productivity.

Many, if not the majority of agronomic investigations into pasture behavior have been conducted using cutting as a measure of production, even where the objective is to provide quidelines for management under grazing.

In a review of the effects of grazing and cutting on pasture. Korte and Harris (1987) quote many authors who have found that these methods of defoliation had different effects on productivity due to nutrient return in animal excreta, treading damage, and selective defoliation by animals-all absent when swards are cut only. Korte and Harris (1987) conclude that the results of cutting experiments may not be applicable to grazing conditions at all. Even where animals have been used to defoliate as required, once this has been acheived they have often then been grazed off outside the experimental area. The feed requirements over this period clearly cannot be ignored if the pastures being investigated are to be the sole source of feed, and if the answers from research are to reflect what will happen in practice. Such studies must be of a system, where forage is provided for the animals at all times. This is the reality in the New Zealand context, and elsewhere where farmers are grazing year round on grass-(generally perennial ryegrass)-clover pasture only, with no crop or crop residue apart from hay or silage.

Another problem is that almost all these investigations, with the exception of Morris (1969) and some others, have been concerned with on and off grazing, rather than 
continuous grazing-it was considered too difficult to get an accurate picture of what was grown while the animals were actually grazing, or to simulate continuous animal grazing mechanically. As a result, up to the early ' 80 's there was little to guide one when grazing on a continuous i.e. set-stocking basis. Yet in New Zealand and frequently overseas. almost all sheep are managed in set-stocked systems.

It has become clear, albeit in hindsight since the research of the $1980^{\circ} \mathrm{s}$, that meaningful answers to questions relating to the management of grazed pastures can only be realistically answered from studies using farmlets, where a certain number of animals are totally fed on each unit and nowhere else. It is important that animals are included in any research on pasture management. They are part of the system and interact strongly with pasture in terms of pattern and amount of defoliation, treading, and nutrient return.

\section{Guidelines when set-stocking}

Continuous grazing, also called set-stocking. is a grazing management system where animals are grazing at a relatively low stocking rate of up to 15 sheep. or two to three cattle per ha, 24 hours a day for anywhere between say 10 days and 4 months.

Over the latter and similar long periods, the stocking rate will be adjusted from time to time to allow for changes in feed availability. The name of the system is to some extent misleading. in that although animals are present all the time, they do not graze each plant every day. Instead, depending on stocking rate, several to many days do elapse between the grazings of any one plant or tiller (Hodgson 1966).

Every farmer knows that if you overstock and consequently overgraze a paddock. that the sown species will disappear and their place will be taken by less productive and often less attractive weed species. What is not as often appreciated is that productivity is diminished by understocking too (Morris 1969). As Smetham (1976) pointed out, there must be a balance point- an optimum stocking rate at which pasture produces at or near maximum, and this will occur at a rate which is neither too high nor too low. Evidence that this is so is seen in the results of Mott (1960) who put together the results of some 24 beef stocking rate experiments, and perhaps most pointedly by Vickery (1972). He measured pasture productivity in terms of carbon fixation, and showed that this was highest at an intermediate continuous stocking rate of 20 sheep/ha, but was lower at 10 and 30 sheep per ha. The question is, when grazing a paddock on a continuous basis, how do you know if you are over or undergrazing? The answer is provided by several reported experiments. Parsons and Johnson (1983) measured what they called the "flow of matter" in pastures on a series of set-stocked farmlets with grazing ranging from severe to quite lax. 
An examination of the results (Figure 1) shows that at light stocking rates (Figure $1 \mathrm{X}$ ) gross photosynthesis is at a maximum. However the proportion of photosynthate used for respiration is high, and so is the amount of matter which dies without being consumed by animals. This emphasises the reality that leaf or other herbage is either eaten by grazing animals, or it dies. Since the life expectancy of such material is very limited, the possibility of death is considerable. Where animal intake per ha is low, animal production per ha will also be low, and an enterprise at this stocking rate is unlikely to be profitable. On the other hand, at a high stocking rate (Figure $1 \mathrm{Y}$ ) animal intake/ha is high, and although gross photosynthesis is reduced because the greater number of animals do not allow the buildup of canopy biomass, the amount of photosynthate used for respiration is lower. The most important feature of partitioning here is that the amount of photosynthate which disappears in senescence and death is a much reduced proportion of total photosynthate compared to that at a low stocking rate. This is because animals are eating most of the herbage before it ages. At an overly high stocking. animals consume most of the herbage leaving behind little if any leaf to fix carbon.

Position $\mathrm{Y}$ on the graph is clearly the balance point being sought, at which productivity of the pasture-animal system is at or near optimum.

Bircham and Hodgson (1983) produced similar results, but expressed the balance in terms of herbage mass. Measurements were taken from farmlets stocked to give a range of sustained herbage mass i.e. weight of herbage above ground level. Production of new growth increased as the sustained herbage mass increased i.e. as the stocking rate decreased (Figure 2). However this was accompanied by an increase in the rate of senescence and death, and therefore a decrease in the net amount of herbage available to the animals. The shape of the net production curve shows that the rate of net herbage accumulation was within $10 \%$ of maximum between a herbage mass of about 900 and 1650 $\mathrm{kg} /$ ha organic matter (equivalent to about 1000 ) and $1800 \mathrm{~kg} \mathrm{DM} / \mathrm{ha}$ ), with a lower rate of accumulation at both high and low levels of sustained herbage mass. A grazier can therefore assess whether pasture is operating at near maximum production by monitoring herbage mass. If it is not within the limits. stock demand may have to be reduced by feeding supplements or selling off stock, or conversely be increased by putting on more stock. Plants grow by fixing carbon dioxide and water in their leaves, and it makes sound biological sense that pasture production is determined by the amount of leaf retained in the canopy. Herbage mass is in effect a measure of the amount of leaf present; in other words a measure of the size of the "factory" fixing carbon. In 1956, Watson demonstrated that the growth rate of both crops and pasture depended on the area of leaf growing on unit area of ground (leaf area index or LAI). For maximum growth rate of ryegrassclover pasture in New Zealand mid-season. the LAI required in the absence of stock is 

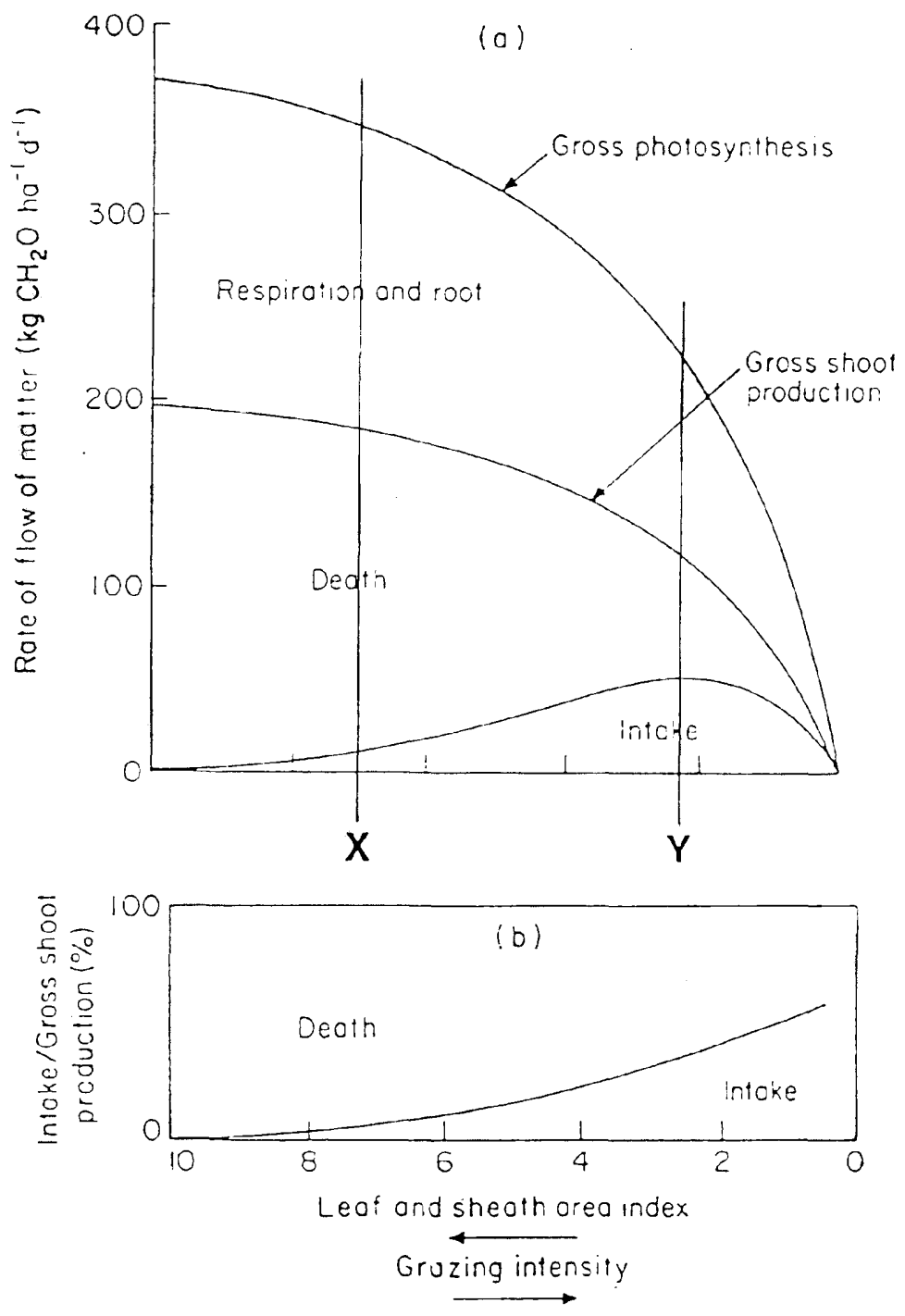

Figure 1.- The flow of matter in a sward grazed at various levels of intensity. The diagram (a) shows the relationship between uptake and loss of matter. and the animal intake that can be achieved in swards maintained at each of a wide range of LAI. The relationship between shoot production. intake and death is redrawn in (b) to describe the proportion of the shoot that is harvested rather than lost to death (Parsons et al., 198.3).

Figura 1.- El flujo de la materia en una pradera pastada a varios niveles de intensidad. El diagrama (a) muestra la relación entre la producción y pérdida de materia. y la ingestión de los animales, en praderas con distinto Indice de Area Foliar. La relación entre producción de hierba, ingestión y muerte se vuelve a representar en (b) para describir la proporción de hierba cosechada por los animales y de la perdida por muerte (Parsons et al., 1983). 
around 4.5-5.0 (Brougham 1956). However Bircham and Hodgson (1983) have shown (Figure 2) that when the animals-grazing-on-pasture system as a whole is considered, this figure is lower and ranges from LAI 2.0 to 4.0. This emphasizes the need to include all facets of systems in studies, if misleading findings are to be avoided.

In practice farmers can estimate herbage mass by eye quite accurately with a little training, although the use of pasture height together with a graph from which the height $x$ weight relationships can be read is easier. Or footware can be used! The desirable range of herbage mass for set stocking ( $1000-1800 \mathrm{~kg}$ DM/ha) equates to $25 \mathrm{~mm}-65 \mathrm{~mm}$ pasture height (Figure 2), or in terms of rubber or leather working boots, between the top of the welt and $10 \mathrm{~mm}$ above the toe (Smetham 1990).

It must be emphasized that the results quoted above strictly speaking apply to ryegrass-dominant pastures growing in a maritime climate. Nevertheless this author contends that the principles apply to pastures worldwide but with minor differences in detail depending on species architecture and climate. In addition seasonal differences in climate, and whether the grasses are reproductive (see later paragraph-"Disturbance of the steady state"), will affect the required balance between pasture and stocking rate (Johnson and Parsons, 1985a).

\section{Guidelines when rotational grazing}

Rotational grazing is a system of managing stock on pasture where the period of defoliation is short enough to avoid removal of regrowth; and with a spell time that allows full recovery of the plants in the pasture. The period of grazing is generally 12 to 24 hours, but may be as long as a week; and the spell anything from 10 days to 10 weeks. This method of stocking is characterised by high stocking rates during grazing of 30 to 300 cows, or 200 to 2000 sheep/ha which arise from concentration of the animals on a small proportion of the farm. An advantage of the rotational system is that feed allocation to the animals can be closely controlled. The system does require adequate subdivision, although this can be acheived using cheap electric fences. As a result of the high stocking rates during grazing, the proportion of herbage harvested by the animals is higher than during continuous grazing (Cambell 1966), and the quality of the regrowth is therefore higher (see section "Pasture quality").

In view of Brougham's (1956) finding, one might assume that to maximise productivity under a rotational grazing system that pastures should be spelled until ceiling leaf area index is achieved before grazing, or at least spelled for long periods e.g. 6 weeks shown by many researchers e.g. Chestnutt et al.(1977) to give greater production than shorter in- 

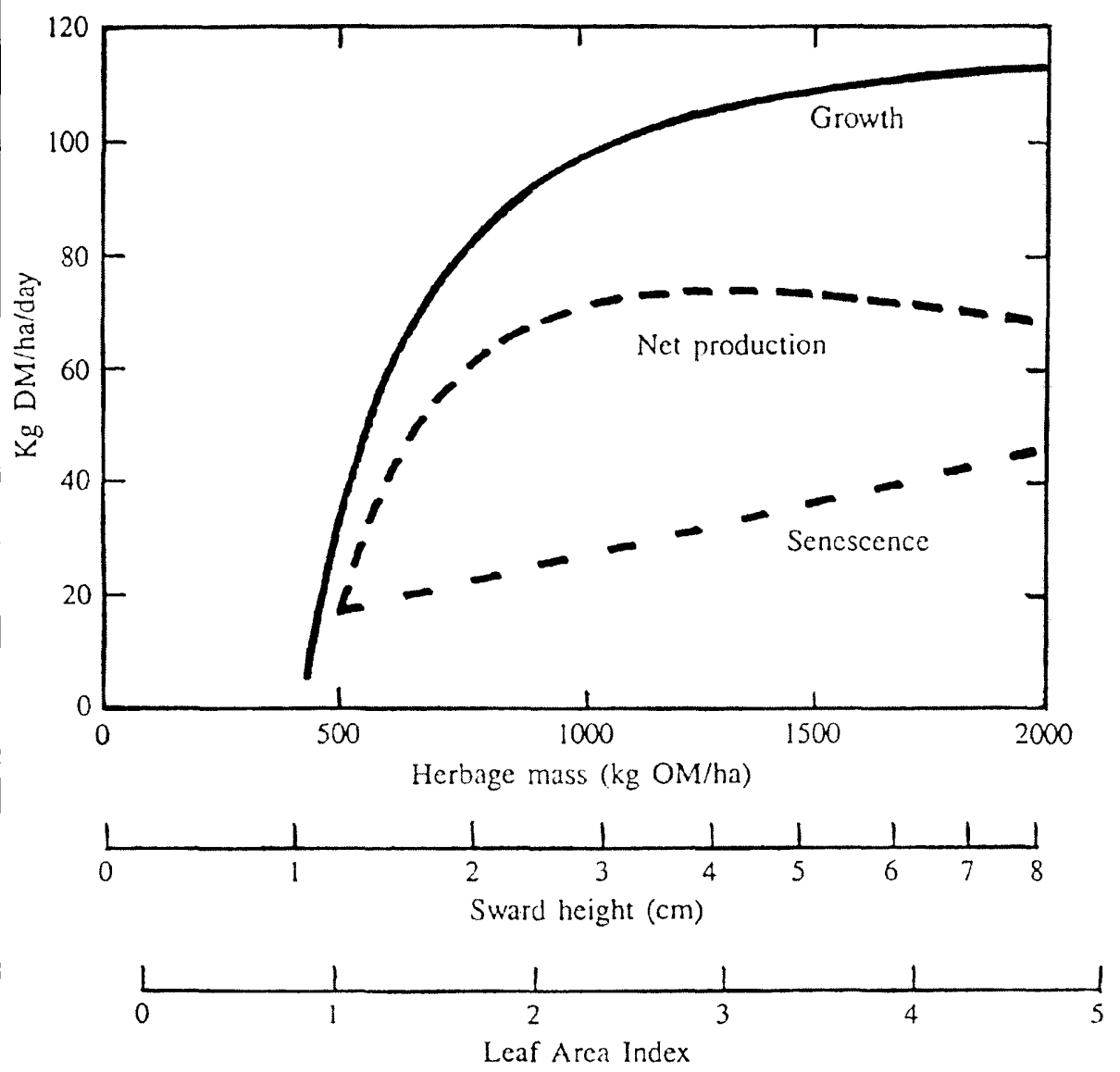

Figure 2.- The influence of herbage mass on rate of herbage growth. senescence, and net production (kg DM/ha/day) in continuously stocked swards grazed by sheep (Bircham and Hodgson, 1983).

Figara 2.- Influencia de la masa de hierba en el crecimiento, senescencia y producción neta $(k g$ MS/ha/dia) en praderas utilizadas por ovejas en pastoreo continuo (Birdam y. Hodgson, 1983). 
tervals. However Harris ( 1978 ) demonstrated that where the rotation length was determined by the need to meet the herbage requirement of grazing animals, guidelines of LAI and set grazing intervals are compromised. This is largely because in rotational systems on typical farms with fixed areas and fixed numbers of stock. the feed demands of the stock determine the interval between grazings and severity. In Harris" experiment animals were fed according to Agricultural Research Council standards, and if they had to be moved to satisfy intake then they were moved, regardless of interval since last grazing.

The results (Figure 3 ) demonstrate that at a constant level of animal production during rotational grazing, a relationship exists between a measure of sustained herbage mass (average stubble biomass) and pasture productivity. Production of the pasture was nearmaximum between about 1700 and $2500 \mathrm{~kg} /$ ha average stubble biomass. This result is in principle the same as that for set stocking, in that average stubble biomass is an indirect measure of the amount of leaf being retained in the canopy over time. Again productivity is lower when the stocking rate is too high, or too low. There is however a difference between set-stocking and rotational grazing in the amount and range of herbage mass required to promote near maximum growth. This is because the build up of dead material, which affects green herbage accumulation, is much slower after the relatively severe defoliation associated with rotational grazing (Hunt, 1971). As a result, rotationally grazed paddocks can be spelled for longer before dead material builds up to the extent that it is affecting production. Consequently the optimum range of herbage mass is greater. In practice average stubble biomass for a grazing unit or property is calculated from assessments made on each paddock on a regular- generally weekly, basis. The system is used by leading dairy farmers in New Zealand. If average stubble biomass drops below the desired range, then supplements are fed to slow down the rotation: if too high, then paddocks will be taken out of the rotation and saved for hay or silage; or the rotation will be speeded up.

\section{Reason for reduced production at high or low stocking rate}

Productivity is severely reduced at high stocking rates when overgrazing occurs. The data of Bircham and Hodgson (1983) indicates that this happens when total herbage mass is below about $700 \mathrm{~kg} \mathrm{DM} / \mathrm{ha}$. At this stage individual tillers are so small that even the high efficiency of the youngest leaves cannot compensate for reduced leaf area (Leafe and Parsons, 1983) and tillers die probably because of insufficient substrate to maintain respiration. At low stocking rates productivity is reduced by the increase of dead material in the canopy, which shades green leaves, and tiller bases (Campbell, 1969), and also by the reduced efficiency of carbon dioxide fixation of leaves initiated and emerging in the sha- 


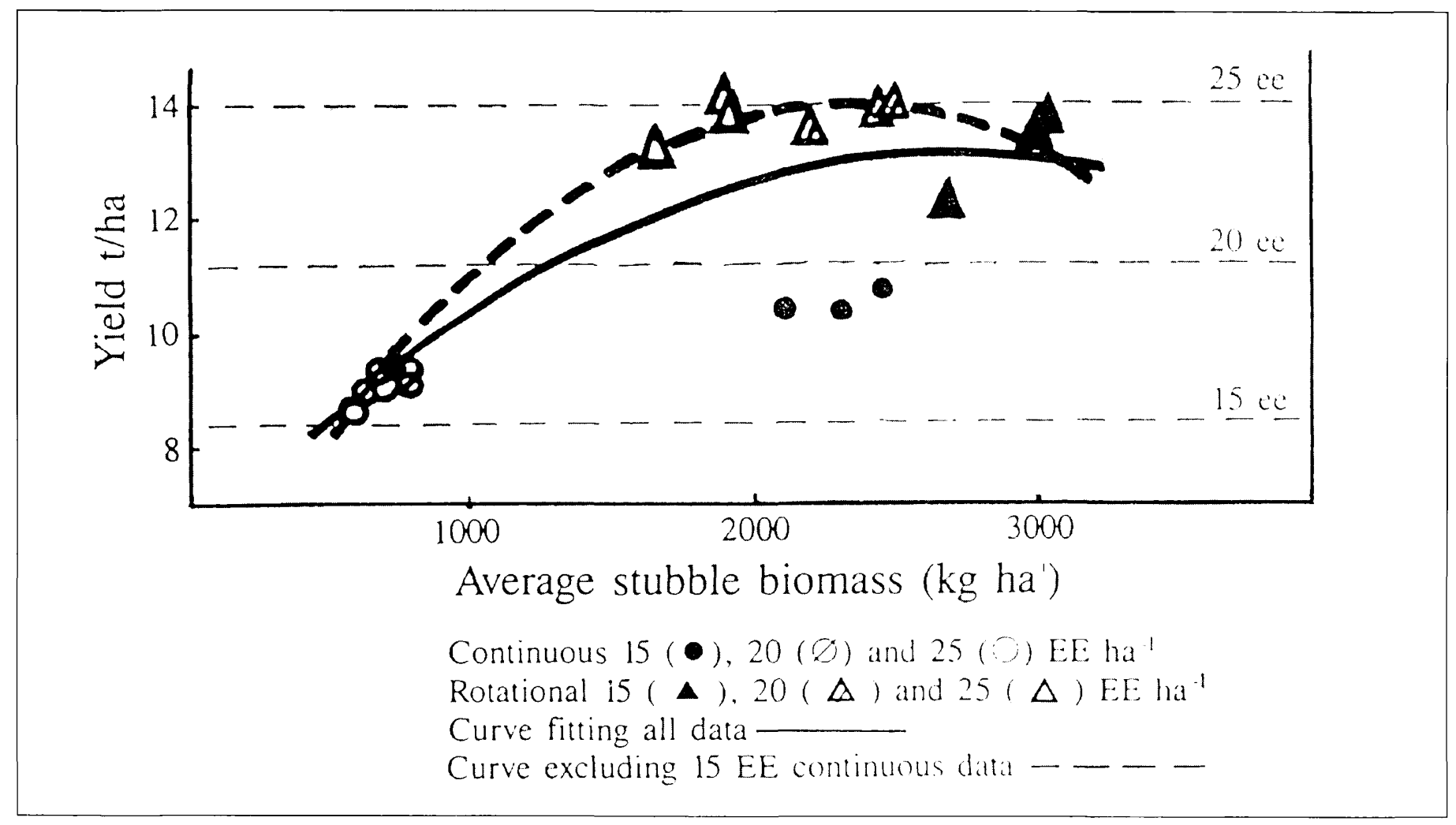

Figure 3.- The relationship between pasture productivity and average stubble biomass at three levels of stocking and under continuous or rotational grazing (Harris, 1978).

Figara 3.- Relación entre la prodacción de la pradera y la biomasa del rastrojo en pastoreo continuo y macional (Harris. 1978 ). 
de of a tall canopy (Woledge, 1977). It is evident therefore that the grazing animal-pasture system tends to be self-limiting, although herbage production is buffered over a moderate range of herbage mass (Harris, 1982).

\section{Disturbance of the steady state}

Relationships between herbage mass and pasture productivity described above apply when pastures are in the "steady state" (Parsons and Johnson, 1986), but reproductive growth of grasses, and changes of growth rate caused by seasonal differences in climate modify these.

\section{Seasonal differences}

Seasonal differences in the relationship between amount of leaf present and productivity arise as a result of differences in temperature, light energy receipt, and moisture through the year. In practice they are generally accomodated by feeding supplements eg in drought, or in winter by rationing grass. However in early spring, or at "turnout" in areas where stock have been winter-housed, the balance between stock numbers and herbage mass is critical, yet at this time little appropriate action is taken in practice if the relationship is not satisfactory. Johnson and Parsons (1985a) showed that stocking of pastures too early in the spring when they have too low a leaf area (herbage mass), permanently impairs the ability of those pastures to catch up, and their level of productivity is always lower in that season than those where turnout occurred at a higher herbage mass. A quantitative consequence of this situation is given by Bircham (1984). Set stocking for lambing on pasture with a herbage mass of only $600 \mathrm{~kg} \mathrm{DM} / \mathrm{ha}$, as commonly occurs in New Zealand, resulted in lamb liveweight output at weaning three months later of only $120 \mathrm{~kg} / \mathrm{ha}$. However where herbage mass was $800 \mathrm{~kg} \mathrm{DM} / \mathrm{ha}$ initially, output was increased considerably to $220 \mathrm{~kg} / \mathrm{ha}$ liveweight. The practical solution is obvious. Continue housing, or supplementary feeding for a further week or two until herbage mass has built up before introducing stock. This solution may not be very popular with farmers but is nevertheless worthy of their attention.

\section{Reproductive growth of the grass component}

Reproductive growth of grasses is another situation where the "steady state" relationship of pastures is altered. In swards remaining ungrazed until cut for hay or silage in summer, about $75 \%$ of tillers become reproductive. 


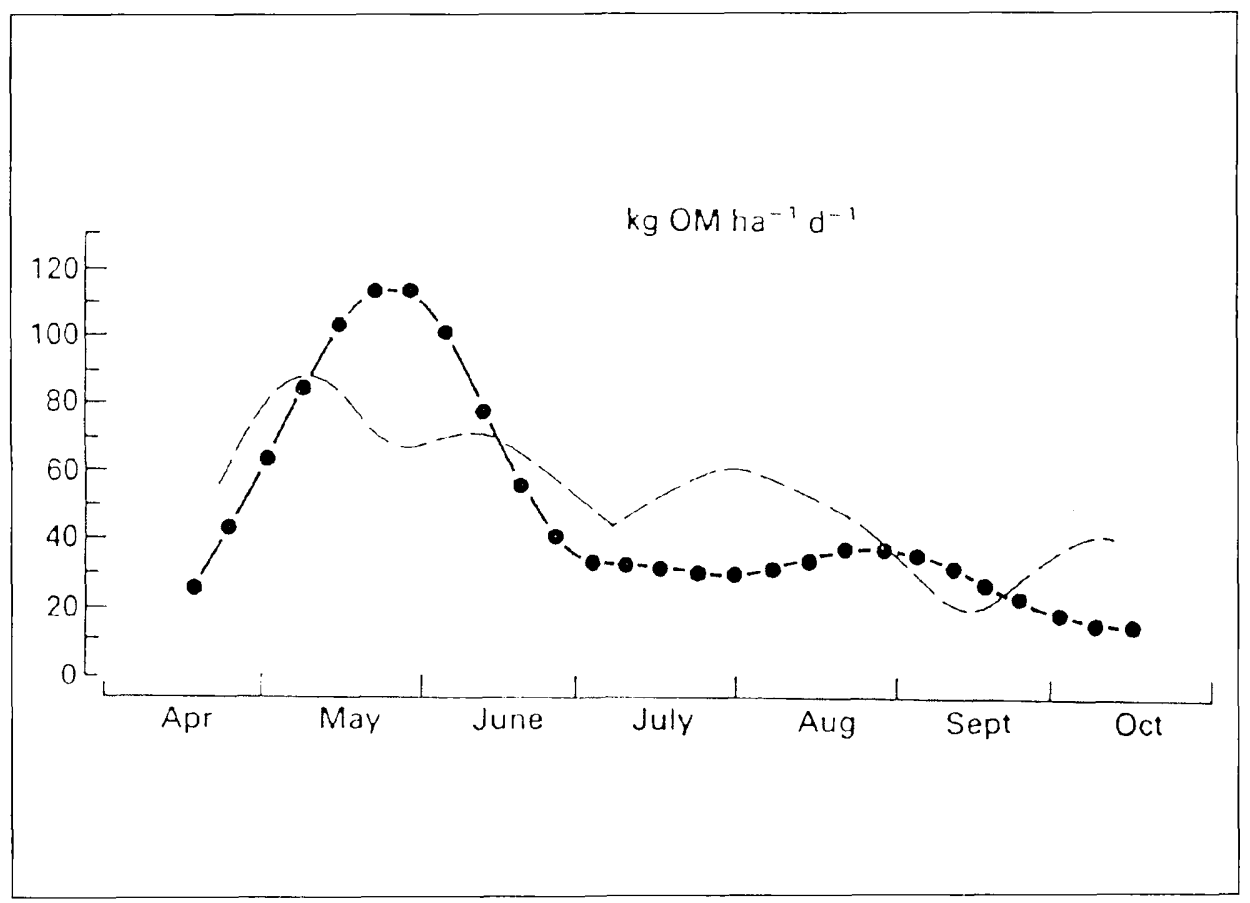

Figure 4.- Seasonal patterns of grass production: the amount harvested (kg OM/ha/day) under a standard 4-weekly overlapping sequence of cuts (.-..) (from Corrall and Fenlon, 1978 quoted by Parsons et al.. 1989). and the amount harvested by sheep ( $\mathrm{kg} \mathrm{OM} / \mathrm{ha} /$ day intake) under continuous grazing in swards maintained close to optimum sward surface height (- - -) (after Orr et al.. 1988 yuoted hy Parsons et al.. 1989).

Figura 4.- Distribución estacional de la producción de hierba: cantidad cosechada (kg MO/ha/día) en secuencias solapadas de cortes cada 4 semanas (.-...) (de Corral y Fenlon. 1978 citado por Parsons et al., 1989). y cantidad cosechada por ovejas ( $\mathrm{kg}$ MO/ha/día) en praderas utilizadas en pastoreo continuo, cura altura se mantuto próxima a la óptima (-..-) (seguin Orr et al., 1988 citado por Parsons et al., 1989). 
However in grazed pastures only 15 to $50 \%$ do so, depending on the closeness of defoliation (Johnson and Parsons, 1985a). Nevertheless control of reproductive growth to prevent such tillers from maturing is desirable for a number of reasons. Firstly, although such pastures yield well in excess of those kept vegetative, much of the weight is stem and therefore of low digestibility. Secondly, the rate of growth of such pastures climbs rapidly in spring to reach a high value, coinciding with the flowering of the main wave of reproductive tiller growth (Figure 4) but then decreases almost as quickly to values for the rest of the season below that of pasture canopies which have been kept in a vegetative state (Leafe et al., 1974; Robson et al. 1989). Such a peak in the growth pattern makes the allocation of feed to animals difficult. Thirdly, reproductive growth inhibits new tiller formation (Jewiss, 1972) and causes abortion of small daughter tillers (Ong, 1978): both of which mean that less green leaves are produced. This reduces animal performance, both directly because of a lower quantity of green leaf, and indirectly because of the lower quality of the herbage on offer (see later section).

\section{FURTHER STUDIES OF ROTATIONAL GRAZING}

Whilst the guidelines for optimising set stocking are quite straightforward, those for rotational grazing are not. For instance no recommendations as to spelling interval or grazing severity are given by Harris (1978) nor was the experiment designed to provide these. However studies of aspects of rotational grazing (Parsons and Penning, 1988) provide answers to these questions. They recognised the need for animals to be incorporated in experimental design, and in this work animal intake is used as the measure of pasture productivity. Detailed measurements of daily rate of photosynthesis, respiration, green leaf production, and dead leaf and sheath build up were also made. Three intervals between defoliation of 12-13 days, 19-23 days, and 30-34 days were the treatments. During the growing season a ryegrass tiller maintains three leaves, with a new leaf appearing every eleven days and living for 33 days (Davies, 1977). Treatment intervals were based on the hypothesis that harvest just before the senescence of the oldest leaf left after close defoliation , or before the senescence of the second oldest leaf, may minimise dead material build up in the canopy, and hence maximise one or several of the attributes being measured.

In fact no clear advantage was obtained from any of the three defoliation intervals for any of the detailed measurements including rate of gross photosynthesis ("P gross" in Figure 5) or green leaf production ("P net" in Figure 5) or senescence and death ("ds" in Figure 5) or total pasture accumulation ("W" in Figure 5). All tended to increase with time. However an analysis of the results in terms of "average growth rate" (see Figure 5) 

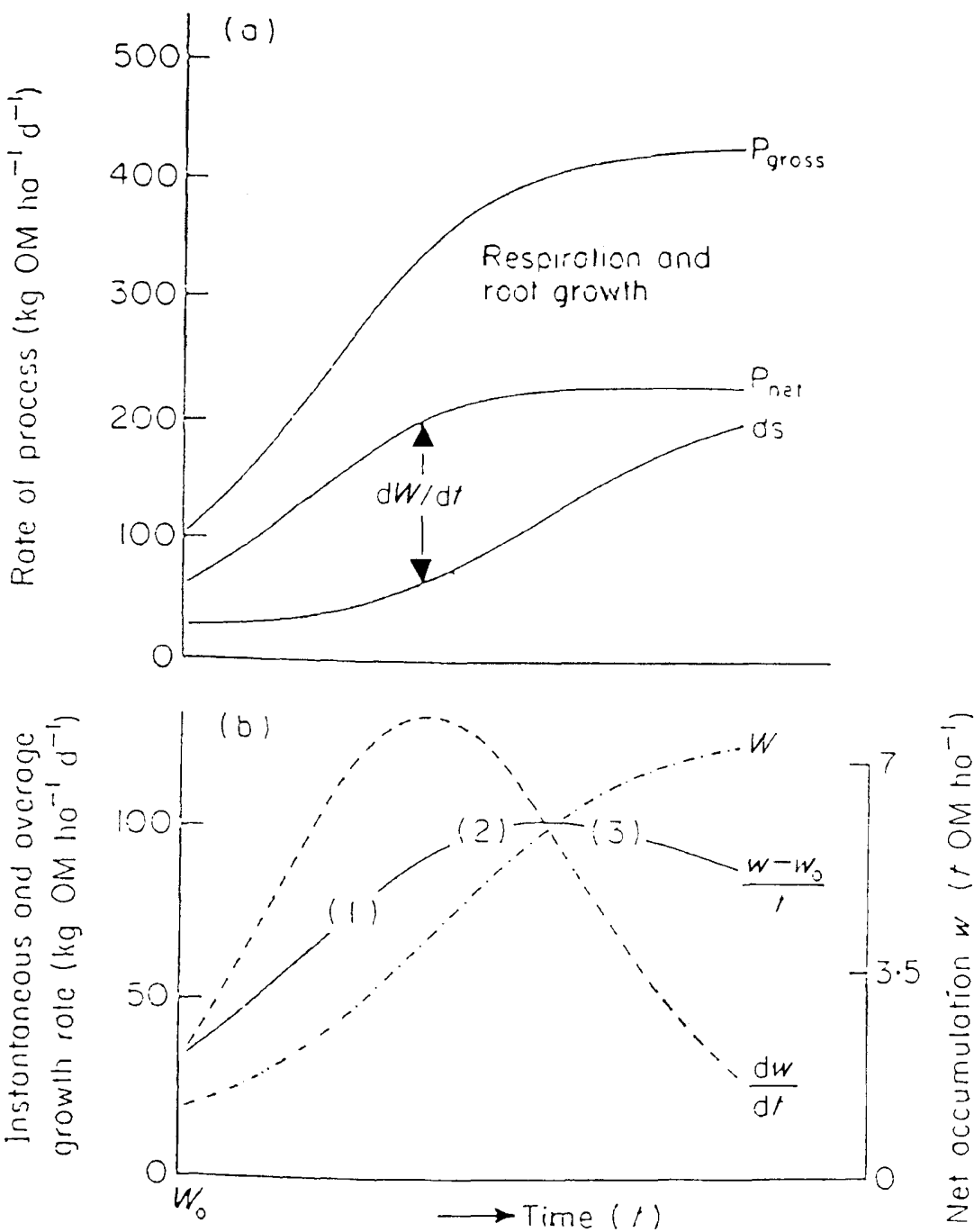

Figure 5.- The effect of the duration of regrowth on the major processes involved in the net accumulation of herbage $(a)$ : gross photosynthesis $\left(P_{\text {gross }}\right)$. gross ( shoot) tissue production $\left(P_{\text {net }}\right)$ and death (ds): and the corresponding changes $(b)$ in the instantaneous growth rate $(\mathrm{dW} / \mathrm{dt})$. the weight of the crop $(\mathrm{W})$ and the average growth rate $\left(\left(\mathrm{W}-\mathrm{W}_{0}\right) / \mathrm{t}\right)$ (Johnson and Parsons, 1988).

Figura 5. - Efecto de la duración del rebrote en los principales procesos relacionados con la anumulacion neta de hierba $(a)$ : fotosíntesis bruta $\left(P_{\text {gross }}\right)$, producción bruta de tejido aéreo $\left(P_{\text {net }}\right)$ y muerte $(d s)$; y sobre los correspondientes cambios (b) de la velocidad de crecimiento (dW/dt), el peso de la cosecha $(W)$ y la velocidad media de crecimiento ( $W$-W $\left.\left.W_{0}\right) / t\right)($ Johnson y. Parsons. 1988). 
showed that the rate of production of green leaf (the animal-preferred part of the canopy) was maximised between 19 and 30 days. The term "average growth rate" $\left[\left(\mathrm{W}-\mathrm{W}^{0}\right) / \mathrm{t}-\mathrm{t}^{0}\right]$ integrates all the major processes involved in the net accumulation of herbage, and is therefore of particular value in the interpretation of plant growth. It showed that the marginal increase in leaf was falling after about 25 days of spelltime, and this is reflected in the total yields of leaf for the growing season which were maximised by the 19-23 day interval (Table 1, and (2) in Figure 5b). As with the results of Bircham and Hodgson (1983), the high rates of gross photosynthesis achieved with spells of longer than 25 days were accompanied by high respiratory load, and increased rates of senescence, both of which reduced net herbage.

\section{TABLA 1}

Yield of leaf from pasture during an 180-day growing season (after Parsons and Penning, 1988).

Producción de hojas de una pradera durante una estación de crecimiento de 180 días (según Parsons y Penning. 1988).

\begin{tabular}{cc}
\hline $\begin{array}{c}\text { Regrowth duration } \\
\text { (days) }\end{array}$ & $\begin{array}{c}\text { Yield } \\
\text { (kg OM/ha) }\end{array}$ \\
\hline $12-13$ & 8.900 \\
$19-23$ & 12.700 \\
$30-34$ & 11.800 \\
\hline
\end{tabular}

The very detailed measurements taken in the investigation described above were used as the basis of a model of grazed pasture behavior constructed by Johnson and Parsons (1985b). This model was then used to investigate the responses of a grazed pasture to different severities of defoliation down to residual LAI 0.5 (Treatment 1 in Figure 6), 0.8 (T2), 1.1 (T3), 3.4 (T4), 5.3 (T5), 6.8 (T6) (Parsons et al., 1988). As might be guessed from the generalised findings already discussed about the effect of dead material on pasture growth, the highest average growth rates were obtained from the closest defoliations (Figure 6) down to LAI 0.5 to LAI 1.1. In results identical in principle to previous findings, leaving high residuals after grazing led to high rates of gross tissue production but tissue death rates and respiration loads were already high, consequently average growth rates were only moderate to low. Close herbage removal had the opposite effect. Note the 


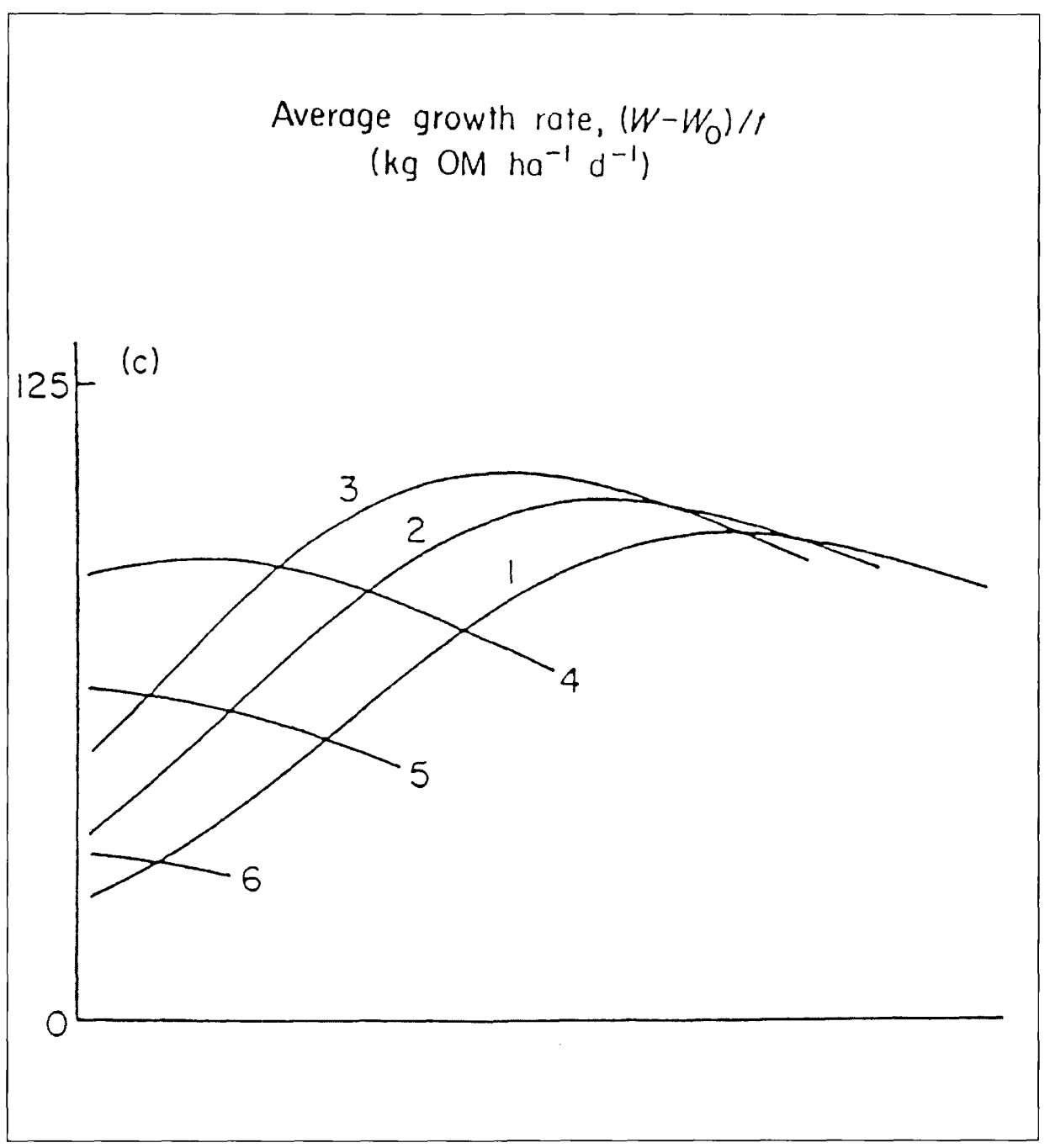

Figure 6.- The effect of the severity of defoliation on the instantaneous growth rate $(\mathrm{dW} / \mathrm{dt})$, the crop weight $(\mathrm{W})$ and the average growth rate. $\left(\mathrm{W}-\mathrm{W}_{0}\right) / \mathrm{t}$. as the duration of regrowth is extended. Residual Leaf Area Index: $1=0.5,2=0.8,3=1.1,4=3.4,5=5.3,6=6.8$.

Figura 6. - Efecto de la severidad de la defoliación sobre la velocidad de crecimiento instantánea (dW/dt). el peso de la cosecha $(W)$ y la velocidad media de crecimiento $\left(W-W_{0} / t\right)$, en función del aumento de la duración del rebrote. Indice de Area Foliar residual: $I=0.5,2=0.8,3=1 . I, 4=3.4,5=5.3,6=6.8$. 
underlying influence of senescence and death, which emphasises the importance of adequate utilisation of the feed on offer to grazing animals. Pasture herbage has only two potential fates; either it is consumed or it dies.

\section{Comparisons of rotational with continuous grazing}

Whilst there is plenty of evidence that pasture yields are higher in total from long spells rather than short, very few experiments demonstrate higher herbage production from rotational grazing when this is compared to set-stocking. One of the most logical comparisons (Parsons et al., 1988) shows an average advantage of $20 \%$ higher herbage yield from rotational grazing. The comparison is fraught with difficulty. Conditions imposed experimentally have often predetermined the outcome. For instance Campbell (1966) failed to find any difference in an experiment using dairy cows, but then the intervals between rotational grazings in this comparison were predetermined, which, from what has been discussed, would have affected pasture production. For example Harris (1978) showed that rotationally grazed swards only give maximum production if they are allowed to operate at a higher range of herbage mass than set-stocked swards. Making comparisons of grazing methods at a fixed interval between grazings which may not allow herbage mass to reach optimum will therefore predetermine or at least bias the result. In the 1970's several comparisons in Gt Britain e.g. Hood (1974), Castle and Watson (1975), aimed to demonstrate that set-stocking of dairy cows was as effective as rotational grazing. Most of these comparisons, like that of Clark et al. (1982) using sheep on New Zealand hill country, were conducted at the same stocking rate. Is it any wonder then with feed demand being identical, that productivity did not differ? In the experiment of Clark et al. (1982) there was no difference between total leaf growth and total leaf removed by the animals. This is due to the ability of pastures to compensate for the pattern and amount of herbage removal by changing the balance between tiller size and tiller number (Bircham and Hodgson, 1983), leading to an equalising of the weight of herbage grown (Jones et al., 1982). This phenomenum is illustrated by the flat topped nature of the response curves in figures 2 . and 3.

Hood's (1974) comparison failed to measure herbage production. the results being in terms of milk produced. Rotational grazing gave a lower milk yield, but since these pastures had to be topped to clear gross surpluses, it is possible the result was determined by pasture quality, whereas yield may have been higher. It is perhaps significant that a survey (Davis et al., 1979) of 22 dairy farming properties comparing rotational with continuous grazing indicated significantly higher milk production from the former method, 
which would suggest the cows were getting either more herbage: or the same amount but at a higher level of quality, from the rotational grazing compared to set-stocking.

Most dairy farmers in New Zealand rotationally graze their cows, and in the comparison of methods conducted by McMeekan and Walsh (1966) the superiority of the rotationally grazed animals in milk production is considered to be due to higher pasture quality (Cooper. 1960) in spite of no difference in total herbage produced (Campbell, 1966).

To avoid some of the problems illustrated above Parsons et al. (1988) used a pasture model (Johnson and Parsons, 1985b) to make the comparison between methods of grazing. A period of time could not be used in the study since leaf area (and hence productivity) changes with time during rotational spells. Therefore the comparison was based on the level of productivity at the same average leaf area (Figure 7) for each method. As quoted at the beginning of this section, Parsons et al. (1988) showed that on average $20 \%$ more herbage is likely to be produced by rotational grazing.

\section{PASTURE QUALITY}

The most important factor influencing pasture quality is the amount of leaf present in the canopy. Also of importance is the proportion of leaf relative to stem and dead material. For instance L'Huillier ( 1987 a) found a strong correlation $\left(r^{2}=0.65\right)$ between the green/dead ratio in cow-grazed pastures and \% digestible dry matter. Most of the topics already discussed above, and especially the guidelines proposed, therefore have relevance to the provision of high quality leafy swards with a low proportion of dead material for animal feeding. Pasture quality gradually declines from early spring through to midsummer (Rattray, 1978) because of a build up of dead material. This is a result of the high herbage allowances offered, and is also a consequence of reproduction in the grass component. However quality also declines because less leaf is produced by grasses in swards where reproduction is allowed to occur.

\section{Dead material and it's influence in the canopy}

Dead matter in the canopy constitutes a loss of potential animal production (see Parsons et al., 1983 above), in addition to interfering positively with plant growth, and reducing herbage quality. One reason for a build-up of dead material in the canopy of grassclover pastures under the New Zealand system is that animals are given high herbage allowances early in the season to maximise animal performance.

Since pasture plant parts have a short life-a ryegrass leaf lives for only 33 days (Davis, 1977) and a white clover leaf for 28 days-herbage not consumed by animals within 


\section{Average growth rate $\left(W-W_{0}\right) / t$ (kg OM ha ${ }^{-1} d^{-1}$ )}

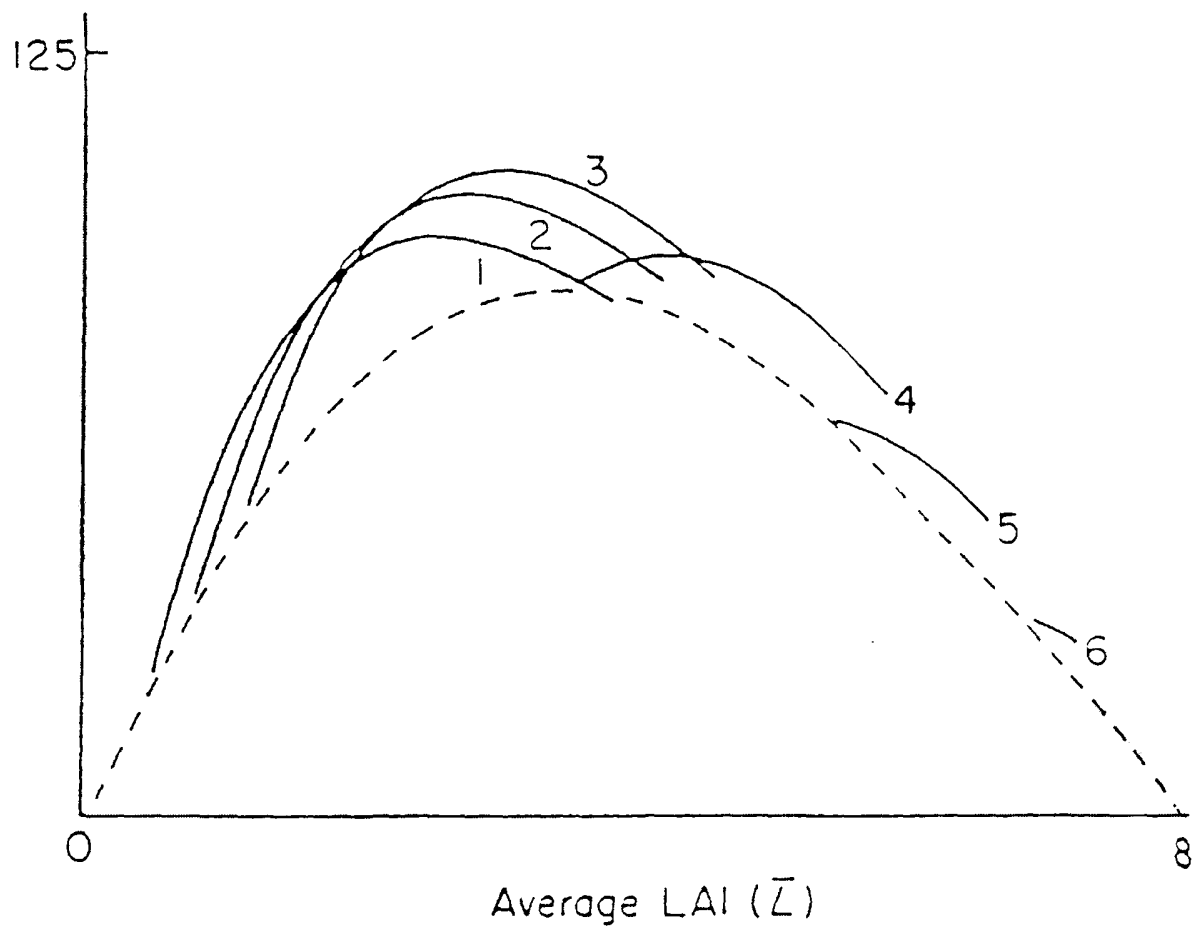

Figure 7. The relationship (continuous line) between the average growth rate acheived and the average LAI ( $\mathrm{L}$ ) sustained when the sward is harvested following the six severities of defoliation (see text) after a range of regrowth durations. The dashed line is the average growth rate (i.e. the rate at which herbage is consumed per ha) in swards maintained at the same average LAI (L) by continuous grazing (Parsons and Penning. 1988).

Figura 7.- Relación (línea continua) entre la velocidad media de crecimiento y el Indice medio de Area Foliar $[L A I(L)]$ del rebrote en el momento del aprovechamiento, en seis distintas intensidades de defoliación del pasto (ver texto) y distintas edades del rebrote. La línea de trazos es la velocidad media de crecimiento ( la velocidad a que la hierba es consumida por ha) en praderas aprovechadas en pastoreo continuo y mantenidas con al mismo Indice de Area Foliar (Parsons y Penning. 1988). 
this limited lifetime will die and so increase the total of dead herbage. Consequently dead material builds up in pastures which are grazed laxly. It accumulates to a greater extent in swards set stocked to leave a high residual leaf area than those grazed closer (Morris, 1969). Similarly when rotationally grazing, Campbell (1969) found that short spells and lax defoliation resulted in the greatest amount of dead material accumulation in the pasture canopy. This pattern is illustrated by the results of Korte et al. (1982). Over early spring and summer rotational grazing to leave a residual LAI of 1 to 3 led to increasing amounts of "dead" with each successive grazing. However grazing to less than LAI 0.9 almost eliminated grass reproductive stubble, and minimised leaf senescence, but maximised green leaf production (Table 2). Another reason for the build up of dead material in the canopy is that some grass tillers become reproductive. As already discussed, a proportion of tillers in the grass population become reproductive over spring and summer. Some of these are rejected by stock and eventually flower and die. In others the growing point is removed by grazing also leading to death of the tiller. Both situations result in an increase of dead matter in the herbage.

TABLE 2

Herbage accumulation 25 October to 11 January (after Korte et al., 1982). Acumulación de hierba desde el 25 de Octubre hasta el 11 de Enero (según Korte et al., 1982).

\begin{tabular}{lrcc}
\hline \multirow{2}{*}{ Management } & \multicolumn{3}{c}{ Herbage (kg/ha) } \\
\cline { 2 - 4 } & Green & Dead & Total \\
\hline Hard grazed & 13820 & 150 & 13970 \\
Laxly grazed & 8640 & 2200 & 10850 \\
\hline
\end{tabular}

Dead material increases in the canopy as the climate and soil environment gets drier with progression from spring to summer, and then falls with the onset of moister conditions in autumn (Hunt, 1971). In practice therefore the pasture canopy tends to contain a maximum of dead matter in late midsummer, and a minimum in winter.

The expression "net herbage" refers to the herbage on offer to stock. It is the difference over time between the weight of new growth and the amount of senescence. Sometimes, depending on temperature and moisture, and particularly the amount of shading in the canopy, net herbage accumulation can be negative (Korte and Sheath, 1979). This is 
often the case in winter (M.L. Smetham. unpubl.) and frequently occurs in New Zealand in pastures saved in autumn ("autumn-saved pasture") for in situ winter grazing, which are shut too early in the autumn. Under these conditions rates of death can eventually be as high as 50-60 kg DM/ha per day (Hunt, 1971).

\section{Reproductive growth in the grass component}

It cannot be emphasised too strongly that the processes of inhibition and abortion of vegetative tillers caused by grass reproductive tiller growth start early in the spring.

Stem elongation in ryegrasses starts as early as the fourth week in the first month of spring, to elevate the inflorescence and therefore growing point above grazing or mower height by the middle of the second month. This is some two months before seedheads actually appear out of the boot, yet the processes of inhibition and abortion start as soon as stem elongation raises the developing floral structure above ground level.

It is vital for two reasons to remove these reproductive apices early in the season, and as soon as they are above grazing height. Firstly the sooner they are removed the less chance there will be that inhibition of tillering will have occurred to any great extent. Secondly, they fairly quickly reach the stage where they are rejected, or are too tough to be broken off by the usual snatch-grazing practised by cattle. Over the last few years dairy farmers in New Zealand have adopted the practice of close mowing after grazing. particularly after the first two or three rounds of grazing the farm in the spring. with the objective of removing developing grass reproductive structures. The strategy seems to be effective but needs to be done early. Good control of reproductive growth results in a significant increase of green leaf, particularly after midsummer (Korte ef al., 1982). Although in the results (Table 2) it is not possible to seperate the effects of reproductive growth from that of senescence on leaf production, much of the increase of green leaf from close defoliations in spring must be due to the major reduction observed in numbers of flowering tillers. In research reported by L Huillier (1987a), reproductive tillers are very clearly implicated in this reduced production of green herbage. Rates of green leaf accumulation were significantly higher where cows were grazed at 4.6 animals/ha so reducing reproductive tillers by two thirds. Total tiller numbers stayed more or less static at around $5000 / \mathrm{m}^{2}$ and therefore green leaf production remained steady. By contrast where the grazing pressure was less, with only 2.8 cows/ha, total tillers rose to nearly $8000 / \mathrm{m}^{2}$ by midOctober, and then dropped steeply to $3200 / \mathrm{m}^{2}$ in February before increasing again. Most of the increase in spring was in reproductive units, and the steep fall in the total population reflects the influence of these on new vegetative tiller numbers. As a result green le- 
af appearance was severely curtailed. A rise in stocking rate has the effect of increasing the proportion of herbage consumed. An investigation of this aspect by L'Huillier (1987b) showed that a low level of utilisation $(10 \%)$ by dairy cows of the herbage on offer resulted in rates of accumulation of only $7 \mathrm{~kg}$ DM/ha/day "green", whereas $60 \%$ utilisation caused $38 \mathrm{~kg} \mathrm{DM} / \mathrm{ha}$ /day "green" to accumulate. Dead material on the other hand accumulated at $39 \mathrm{~kg} \mathrm{DM} / \mathrm{ha} /$ day, and $11 \mathrm{~kg} \mathrm{DM} / \mathrm{ha} /$ day respectively. No differences occured in total herbage accumulation.

These levels of utilisation, equivalent to the stocking rates of 2.8 and 4.6 cows $/$ ha respectively, illustrate the benefits of imposing grazing pressure to curtail reproductive tillers. Rates of green leaf accumulation in this investigation were significantly higher at the highest level of utilisation from late spring through to mid-summer, but not over the rest of the year, presumably because of the absence then of reproductive activity. Apart from the effect of the overall stocking rate, Korte and Harris (1987) give convincing evidence of the effectiveness of two hard grazings in late spring and early summer in reducing reproductive tillers, and subsequently increasing the number of daughter and total vegetative tillers. However the timing and number of grazings to restore satisfactory vegetative growth has not yet been satisfactorily resolved. Under rotational grazing Butler and Chu (1988) have shown that close grazing below $450 \mathrm{~kg}$ DM/ha residual herbage mass was effective but consider that frequent grazings at not less than 14 days interval may be more important for control. This may well mean a temporary drop in milk yield where dairy cows are concerned, but overall lactation yield is increased, with less dead matter and more green leaf in the pastures in mid to late summer (Thomson et al., 1984). Bryant (1982) obtained a 7\% increase in total lactation milk yield by mowing after grizing even though this farmlet study was conducted at a high stocking rate. In addition cous on this treatment also made significant weight gains, unlike the control animals. In the absence of specific measurement one can only assume that increased leaf production was responsible for these results. In set-stocked swards removal of most reproductive apices can be achieved by grazing to a sufficiently low residual. For New Zealand ryegrass-clover dryland pastures Thompson and MacEwan (1983) found this threshold to be 1400-1600 kg $\mathrm{DM} / \mathrm{ha}$. This is still within the range of herbage mass promoting near maximum production of the animal-grass system when set-stocking and so should be easily acheived.

Growth regulators inhibiting stem elongation have also been shown to increase leaf production in spring. and in some cases increase animal growth rates as well, following a reduction in grass reproductive growth (Leonard et al., 1985).

Dead material builds up as a result of uncontrolled, or late control of grass reproductive growth. At other times of the year a reasonable level of utilisation will ensure that only minimal amounts of ungrazed herbage will age and die. Keeping herbage mass 
within the guidelines suggested earlier will, by virtue of function, keep dead matter at a moderate level.

From another viewpoint, the results of L'Huillier (1987b) suggest that a utilisation of $60 \%$, or an herbage allowance of just under twice the animal requirement is necessary to maintain pasture at a level of quality to promote good animal production during the growing season. For instance Francis and Smetham (1985) obtained swards with a quality of $74 \%$ digestible dry matter and $74-87 \%$ of green herbage content following utilisation at previous grazings of just over $60 \%$.

In practice set-stocked pastures almost always get out of control after midsummer and if high performance is desired, stock have to be given high allowances to allow selection. A better approach may be to prepare pasture for such animals by heavy grazing with store stock to obtain high utilisation and subsequent high quality swards. Although such treatment initially reduces the amount of green herbage produced, the proportion and amount of dead material is substantially reduced with a corresponding increase in overall quality of the regrowth (Stevens and Smetham, 1984).

\section{CONCLUSIONS}

This discourse has shown that green leaf in pasture is of the utmost importance. The sustained amount of leaf determines productivity, and the quantity of leaf present at any one time affects the value of the forage for animals. Substantial dead material on the other hand indicates that herbage mass is beyond the range for near maximum animal-pasture system productivity. Dead material interferes with green herbage accumulation, and dilutes the quality of herbage on offer.

Pastures and grazing animals interact, and because of this, maximum productivity of the system is dependant on the acheivement of a balance between components which is mutually advantageous.

\section{ACKNOWLEDGMENT}

I thank Warwick Harris for helpful criticism during the preparation of this manuscript. 


\section{BIBLIOGRAPHIC REFERENCES}

BIRCHAM. J.S.. 1984. Pattern of herbage growth during lactation and level of herbage mass at lambing: their significance to animal production. Proceedings of the New Zealand Grass/and Association. 45, 177-83.

BIRCHAM. J.S.: HODGSON. J., 1983. The influence of sward condition on rates of herbage growth and senescence in mixed swards under continuous stocking management. Grass and Forage Science, $\mathbf{3 8}$, 323-31.

BOSWELL. C.C.. 1977. Effect of cutting regime on pasture production. New Zealand Journal of Experimental Agriculture, 5, 403-8.

BROUGHAM. R.W. 1956. The rate of growth of short rotation ryegrass pastures in late autumn. winter and eraly spring. New Zealand Journal of Science and Technology, 38A, 78-87.

BROUGHAM. R.W., 1959. The effect of frequency and intensity of grazing on the productivity of a pasture of short rotation ryegrass and red and white clover. New' Zealand Journal of Agricultural Research, 2. 1232-48.

BRYANT, A.M.. 1982. Effect of mowing before and after grazing on milk production. In: Proceedings of the Conference on Dairy Production from Pasture, 381-2. Ed. K.C. MACMILLAN and V.K. TAYLOR. New Zealand and Australian Societies of Animal Production. Ruakura. New Zealand.

BUTLER. B.M.: CHU. A.C.P.. 1988. The influence of spring grazing management on pasture quality. Proceedings of the New Zealand Grassland Association, 49, 131-4.

CAMPBELL. A.G., 1966. Grazed pasture parameters. 1. Pasture dry matter production and availability in a stocking rate and grazing management experiment with dairy cows. Journal of Agricultural Science. Cambridge. 67. 199-210.

CAMPBELL, A.G., 1969. Grazing interval. stocking rate and pasture production. New Zealand Journal of Agricultural Research, 12, 67-74.

CASTLE. M.E.: WATSON. J.N.. 1975. Further comparisons between a rigid rotational Wye College system and other systems of grazing for milk production. Journal of the British Grassland Society: $30.1-6$.

CHESTNUTT, D.M.B.; MURDOCH, J.C.; HARRINGTON, F.J.: BINNIE, R.C., 1977. The effect of cutting frequency and applied nitrogen on the production and digestibility of perennial ryegrass. Journal of the British Grassland Socien, 32, 177-83.

CLARK. D.A.: LAMBERT. M.G.: CHAPMAN. D.F., 1982. Pasture management and hill country production. Proceedings of the New Zealand Grassland Association, 43, 205-214.

CLARK. JENNIFER.; KAT, C., 1974. The effects of changes in heights of cutting and growth on the digestible organic matter production and botanical composition of perennial pasture. Journal of the British Grassland Societs; 29. 269-73

COOPER, M.M.. 1960. Pasture management. Journal of the King's College Agricultural Society. University of Durham. 15. 5-10.

DAVIES, A.. 1977. Structure of the grass sward. Proceedings of the Intemational Meeting on Animal Production from Temperate Grassland, 36-44.

DAVIS. W.I.C.: CROMACK. J.: DAVIES. E.I.: PRYTHERCH, A.: ROWLANDS, P., 1979. Continuous grazing by dairy cows. Grass and Forage Science, 34, 69-70.

FRANCIS, S.M.: SMETHAM, M.L., 1985. Pasture utilisation and its effect on herbage quality. Proceedings of the New Zealand Grassland Association, 46. $221-5$.

HARRIS. W.. 1978. Defoliation as a determinant of growth persistence and composition of pasture. In Plant Relations in Pastures, 67-85. Ed. J.R. WILSON. CSIRO. Melbourne. 
HARRIS. W.. 1982. Herbage production by ryegrass. tall fescue and phalaris at different stocking rates. Procesedings of the New Zealand Grassland Association, 43, 109-117.

HODGSON, J., 1966. The frequency of defoliation of individual tillers in a set-stocked sward. Joumal of the British Grassland Society, 21, 258-63.

HOOD. A.E.M., 1974. Intensive stocking of dairy cows. Journal of the British Grassland Society: 29. 63-7.

HUNT, W.F. 1971. Leaf death and decomposition during pasture regrowth. New Zealand Journal of Agricultural Researh. 14. 208-18.

JEWISS. O.K.. 1972. Tillering in grasses-its significance and control. Journal of the British Grassland Society; 27. 6. -82 .

JOHNSON. I.R.: PARSONS. A.J.. 1985a. Use of a model to analyse the effects of continuous grazing managenents on seasonal patterns of grass production. Grass and Forage Science. 40, 449-58.

JOHNSON. I.R.: PARSONS. A.J.. 1985b. A theoretical analysis of grass growth under grazing. Journal of theoretical Bioleg!: 112, 345-67.

JONES. M.B.; COLLETTT. B.: BROWN. S., 1982. Sward growth under cutting and continuous stocking management: sward canopy structure, tillering density and leaf turnover. Grass and Forage Science, 37, 67-73.

JONES, M.G. 1933. Grazing management and its influence on the sward Pt 2. The management of a clovery sward and its effects. Empire. Journal of Experimental Agriculture, 1. 122-8.

KORTE. C.J.: HARRIS. W.. 1987. Effects of grazing and cutting. In: Managed Grasslands. 71-9. Ed. R.W. SNAYDON. Elsevier. Amsterdam.

KORTE, C.J.: HARRIS, W., 1987. Stolon developement in grazed 'Grasslands Nui' perennial ryegrass. New' Zealand Journal of Agricultural Research, 30. 139-48.

KORTE. C.J.: SHEATH. G.W.. 1979. Herbage dry matter production: the balance between growth and death. Proceedings of the New Zealand Grassland Association, 40. 152-61.

KORTE. C.J.: WATKIN. B.R.: HARRIS, W.. 1982. Use of residual leaf area index and light interception as criteria for spring grazing management of a ryegrass dominant pasture. Now Zealand Journal of Agricultural Research, 25, 309-19.

LEAFE. E.L.: STILES, W.: DICKINSON. SARA. E.. 1974. Physiological processes influencing the pattern of productivity of the intensively managed sward. Proceedings of the 12 th Intemational Grass/and Congress, $442-57$.

LEAFE. E.L.: PARSONS. A.J., 1983. Physiology of growth of a grazed sward. Proceedings of the I4th International Grassland Congress, 403-6.

LEONARD. W.F.; BRUCE. S.J.; RUSSELL. A.J.; COOK. M.R.. 1985. Chemicals for pasture renovation and improvement of pasture quality. Proceedings of the New Zealand Grassland Association, 46, 77-82.

L'HUILLIER, P.J.. 1987a. Tiller appearance and death of Lolium perenne in mixed swards grazed by dairy cows at two stocking rates. Ne'n Zealand Journal of Agricultural Research, 30, 15-22.

LHUILLIER, P.J.. 1987b. Effect of dairy cattle stocking rate and degree of defoliation on herbage accumulation and quality of ryegrass-white clover pasture. New Zealand Journal of Agricultural Research, 30, 149-57.

MATCHES, A.G., 1966. Influence of intact tillers and height of stubble on growth responses of tall fescue (Festuca arundinace Schreb.). Crop Science, 6, 484-7.

MORRIS. R.M., 1969. The pattern of grazing in 'continuously' grazed swards. Journal of the British Grassland Societs, 24, 65-70. 
MOTT. G.O.. 1960. Grazing pressure and the measurement of pasture production. Proceedings of the sth International Grassland Congress, 606-11.

ONG. C.K., 1978. The physiology of tiller death in grasses. I. The influence of tiller age, size and position. Joumal of the British Grassland Society; 33. 197-203.

PARSONS. A.J.: JOHNSON. I.R.. 1986. The physiology of grass growth under grazing. In Grazing. 3-13. Ed. J. FRAME. Occasional Symposium No 19. British Grassland Socieț:

PARSONS. A.R.: PENNING. P.D.. 1988. The effect of duration of regrowth on photosynthesis, leaf death and the average growth rate in a rotationally grazed sward. Grass and Forage Science, 43. 15-27.

PARSONS. A.J.: JOHNSON, I.R.: HARVEY, A., 1988. Use of a model to optimise the interaction between frequency and severity of intermittent defoliation and to provide a fundamental comparison of the continuous and intermittent defoliation of grass. Grass and Fortge Science, 43, 49-59.

PARSONS, A.J.: LEAFE, E.L.; COLLETT. B.: LEWIS. J., 1983. The physiology of grass growth under grazing. 2. Photosynthesis, crop growth. and animal intake of continuously grazed swards. Journal of Applied Ecology: 20. 127-39.

RATTRAY. P.V.. 1978. Effect of laming date on production from breeding ewes and on pasture allowance and intake. Proceedings of the New Zealand Grassland Association, 39, 98-107.

ROBSON. M.J.: PARSONS. A.J.; WILlIAMS. T.E., 1989. In: Grass: Its Production and Utilisation. 38-40. 2nd edit. Ed. W. HOLMES. Blackwell. Oxford

SMETHAM, M.L.. 1976. The influence of herbage utilisation on pasture production and animal performance. Proceedings of the New Zealand Grassland Association, 37.91-103.

SMETHAM, M.L., 1990. Pasture management. In: Pastures:their ecology and management.197-240. Ed. R.H.M. LANGER. Oxford University Press. Auckland.

STEVENS. D.R.: SMETHAM. M.L.. 1984. Stubble management of hay aftermath. Proceedings of the New Zealand Grassland Association, 45, 225-9.

THOMPSON. K.F.: MACEWAN, J.. 1983. Management of the farm to acheive lamb growth. In: Lamb Growth. 111-21. Ed. A.S. FAMILTON. Animal Industries Workshop. Lincoln College. New Zealand.

THOMSON. N.A.: LOGAN. J.F.: MCCALLUM, D.A.. 1984. Herbage allowance, pasture quality and milkfat production as affected by stocking rate and conservation policy. Proceedings of the Nen' Zealcmd Society. of Animal Production. 44.67-70.

VICKERY. P.J.. 1972. Grazing and net primary production of a temperate grassland. Journal of Applied Ecology; 9. $307-14$

WATSON. D.J.. 1956. Leaf growth in relation to crop yield. In: The growth of leares, 141-150. Ed. F.L. MILTHORPE. Butterworths. London.

WOLEDGE. J., 1977. The effect of shading and cutting treatments on the photosynthetic rate of ryegrass leaves. Annals of Botany; 41. 1279-86. 


\section{EL MANEJO DE PRADERAS EN PASTOREO}

\section{RESUMEN}

Se examina la investigación existente sobre el manejo de pastos, así como las posibles razones sobre la dificultad de aplicar en la práctica los resultados de esta investigación. Se proponen unas directrices para pastoreo continuo y rotacional, basadas en las características de la masa de la pradera. Se examinan las razones de las bajas producciones del sistema pasto-animal cuando la masa de hierba disponible es abundante y cuando es escasa. Se analiza la variación de la relación entre la masa de hierba y la productividad debida a diferencias estacionales del clima y del ciclo reproductivo de la hierba. Se dan los resultados de estudios recientes del efecto del intervalo y de la severidad del pastoreo sobre la producción, en pastoreo rotacional. Se hacen comparaciones entre la producción obtenida en pastoreo rotacional y en pastoreo continuo, teniendo en cuenta las dificultades de establecer estas comparaciones. La calidad del pasto se define en términos de materia verde y de materia muerta. Se examina la influencia del manejo en la consecución de distintos niveles de utilización y en el control del crecimiento reproductivo de la hierba.

Se concluye que la cantidad de hoja presente en la masa de hierba tiene una gran influencia sobre la productividad de la pradera, y sobre su valor para alimentación animal. La presencia de material muerto puede interferir con la productividad de la hierba y, a su vez, reducir su calidad como alimento para los animales. Hay una fuerte interaccion pasto-animal, consiguiéndose la máxima productividad cuando se alcanza un balance óptimo entre los dos componentes.

Palabras clave: Pastoreo continuo, pastoreo rotacional. 